\title{
Penggunaan Media Big Book untuk Meningkatkan Literasi Siswa Kelas Satu Madrasah Ibtidaiyyah
}

\author{
Siti Aisah* \& Setia Rini \\ Institut Agama Islam Negeri Salatiga \\ *Email korespondensi: buaisah78@gmail.com
}

\begin{abstract}
The background of this research is the lack of students' literacy skills, especially reading skills after a long time of online learning, the purpose of this research is to find out the benefits of using big books in the habituation activities of class 1 MI Darussalam Sumowono in the field of literacy skills. This research uses a descriptive qualitative approach with the research subjects of Class I students of MI Darussalam Sumowono, Sumowono District, Semarang Regency. The results of this study are those after the teacher uses the big book media for reading activities, students' literacy skills include listening, speaking, reading and writing skills are very good, this is evidenced by the fluent reading skills of class I students of MI Darussalam reaching $65 \%$ in the sufficient category, active students in performance through group discussions, products in the form of small books or mini books and the final evaluation reached $89.28 \%$ in the good category.
\end{abstract}

Keyword: Big Book Media, Literacy Skills

\begin{abstract}
Abstrak
Latar belakang dari penelitian ini adalah kurangnya kemampuan literasi siswa terutama keterampilan membaca setelah sekian lama pembelajaran dilaksanakan secara daring, tujuan dari penelitian ini adalah untuk mengetahui manfaat penggunaan big book dalam kegiatan pembiasaan kelas 1 MI Darussalam Sumowono dalam bidang kemampuan literasi. Penelitian ini dengan pendekatan kualitatif deskriptif dengan subyek penelitian siswa Kelas I MI Darussalam Sumowono, Kecamatan Sumowono, Kabupaten Semarang. Hasil dari penelitian ini adalah setelah guru memanfaatkan media big book untuk kegiatan membaca, kemampuan literasi siswa meliputi keterampilan menyimak, berbicara, membaca dan menulis sangat baik, hal ini dibuktikan dengan keterampilan membaca lancar siswa kelas I MI Darussalam mencapai 65 \% dalam kategori cukup, keaktifan siswa dalam unjuk kerja malalui diskusi kelompok, produk berupa buku kecil atau mini book serta evalauasi akhir mencapai $89.28 \%$ dalam kategori baik.
\end{abstract}

Kata kunci: Media Big Book, Kemampuan Literasi 


\section{A. Pendahuluan}

Penyelenggaraan pendidikan di Indonesia menjadi berubah-ubah sejak adanya pandemic Covid-19 sejak awal Tahun 2020, saat suatu daerah berada zona merah, maka pembelajaran dilaksanakan secara daring dan jika berada pada zona hijau, maka dengan bertatap muka. Penyelenggaraan pembelajaran tatap muka pada masa pandemi covid-19 mulai dilaksanakan semenjak adanya keputusan bersama Menteri Pendidikan dan Kebudayaan, Menteri Agama, Menteri kesehatan, dan Menteri Dalam Negeri Republik Indonesia Nomor HK;01.08/MENKES/424/2021, dan Nomor 440-717 Tahun 2021 tentang panduan penyelenggaraan pembelajaran tahun pelajaran 2021/2022 dengan pembelajaran tatap muka terbatas dengan menerapkan protokol kesehatan (Husna \& Sugito, 2021).

Setelah diperbolehkannya pembelajaran tatap muka siswa sangat antusias dalam belajar di madrasah, yang selama ini hanya bisa belajar di rumah dengan cara daring. Namun, di sisi lain guru juga harus mempersiapkan media yang tepat bagi siswa terutama kelas I Madrasah Ibtidaiyyah yang berusia antara 6-7 tahun. Pada usia 6-7 tahun kemampuan kognitif anak masih pada tahapan pengetahuan dan pemahaman yang bersifat terbatas, apabila dihubungkan dengan taksonomi bloom, pada fase ini anak berada pada tingkatan C1 (mengingat) dan C2 (memahami) dan ada beberapa yang sudah mampu memasuki tingkatan C3 (menerapkan), sebagai contoh saat siswa belajar membaca, maka ia akan belajar mengeja bacaan, menyalin tulisan dan sudah mampu berbicara saat proses pembelajaran, pada tahapan ini anak kelas Satu harus diberikan kosakata yang sering dipakai dalam kehidupan sehari-hari (Oktavia, 2021).

Kosa kata dapat diperoleh melalui kegiatan membaca, karena membaca dapat dijadikan sebagai pintu gerbang yang memegang peranan penting dalam keseluruhan kehidupan manusia terutama membuat kontak dan berkomunikasi dengan pikiran dan imajinasi serta sebagai dasar pendidikan untuk menulis dan berhitung (Pratiwi, 2019). Membaca dapat diartikan proses kegiatan mencocokkkan huruf atau melafalkan lambang-lambang bahasa tulis dan juga dapat berarti sebagai proses memetik serta memahami arti atau makna yang 
terkandung dalam bahasa tulis (Harras, 2011). Perintah membaca bersumber dari firman Allah SWT surat Al-alaq ayat 1-5:

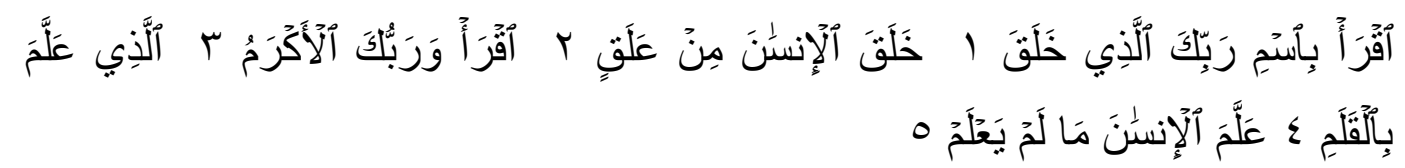

Artinya: " bacalah dengan (menyebut) nama Tuhanmu yang menciptakan (1), Dia telah menciptakan manusia dari segumpal darah(2), bacalah, dan Tuhanmu yang paling pemurah (3), yang mengajar (manusia) dengan perantaraan kalam (4), dia mengajarkan kepada manusia apa yang tidak diketahuinya(5)".

Allah Swt memerintah Nabi Muhammad untuk membaca, sedang beliau tidak pandai membaca dan menulis, maka dengan kekuasaan Allah Swt beliau dapat mengikuti ucapan malaikat Jibril AS dan memahaminya dengan sempurna (Bahaudin \& Zaini, 2007: 614). Perintah membaca sangatlah penting karena hal yang utama dan pertama untuk menambah ilmu pengetahuan, setelah ayat ini diturunkan kepada Nabi Muhammad SAW, maka beliau memulai menyebarkan syariat agama Islam (Dirwan dkk., 2018).

Membaca merupakan salah satu kemampuan dalam literasi, dalam pengertian luas literasi memiliki arti kemampuan dalam berbahasa meliputi menyimak, berbicara, membaca dan menulis (Bu'ulolo, 2021). Untuk meningkatkan kemampuan literasi peran guru sangat penting serta ketersediaan media yang sesuai untuk mempermudah dan memberikan pemahaman, lebihlebih pada anak usia 6-7 tahun atau siswa kelas I Madrasah Ibtidaiyyah, guru dianjurkan menyediakan pembelajaran yang menarik dan menyenangkan bagi siswa dengan menggunakan media pembelajaran yang dapat membangkitkan keinginan dan minat peserta disik serta meningkatkan motivasi dan rangsangan dalam kegiatan pembelajaran (Mahsun \& Koiriyah, 2019).

Penggunaan media yang menarik sangat diperlukan oleh siswa terutama setelah sekian waktu anak jenuh belajar di rumah secara daring karena pandemi covid 19, seperti halnya yang dialami oleh siswa kelas I MI Darussalam Sumowono, Kabupaten Semarang. Pada awal masuk pembelajaran tatap muka masih ditemukan siswa yang belum mampu membaca bahkan belum hafal huruf. Dengan demikian guru perlu membuat media yang menarik untuk keterampilan membaca siswa yaitu dengan menggunakan big book. Big book yang akan digunakan adalah tema 3 yaitu kegemaranku karena tema sebelumnya 
pembelajaran masih dilakukan secara daring penuh. Dari dua puluh delapan siswa, terdapat tiga siswa yang belum hafal huruf, delapan siswa sudah hafal huruf namun belum mampu membaca, dua belas siswa baru dapat membaca suku kata dan baru lima siswa yang sudah lancar membaca Oleh karena itu guru perlu kreatif untuk membuat media membaca dengan harapan keterampilan literasi siswa kelas I dapat meningkat.

Big book merupakan buku berukuran besar dengan ukuran 14 inci x 12 inci atau $34,5 \mathrm{~cm} \mathrm{X} 49 \mathrm{~cm}$, memiliki ilustrasi dan huruf cetak berukuran besar digunakan sebagai media pembelajaran membaca dengan cara berkelompok agar anak atau siswa mampu membaca dan memahami isi teks di dalamnya (Karyadi, 2018). Big book biasanya digunakan di kelas awal karena memiliki karakteristik yang sesuai dengan kebutuhan siswa, guru dapat memilih atau membuat big book yang isi cerita dan temanya disesuaikan dengan minat siswa atau dengan tema mata pelajaran (Alpusari dkk., 2021).

Melalui membaca dengan media big book, akan timbul keberanian dan keyakinan dalam diri siswa bahwa mereka "sudah bisa" membaca, dapat mengembangkan semua aspek kebahasaan, dapat diselingi percakapan yang relevan mengenai isi cerita bersama siswa sehingga topik bacaan semakin berkembang sesuai pengalaman dan imajinasi siswa (Puspaningrum, 2015). Seorang guru hendaklah menyiapkan media pembelajaran yang menyenangkan dan mudah difahami oleh siswa. Perintah pembelajaran menyenangkan sebagaimana hadits Rosulullah SAW:

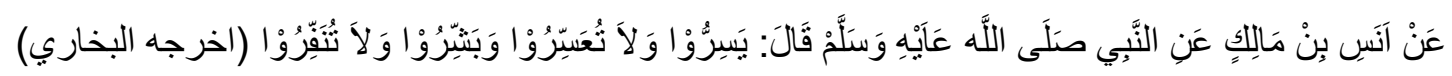

Artinya: Dari Anas bin Malik, dari Nabi SAW beliau bersabda: mudahkanlah jangan dipersulit, dan gembirakanlah jangan kalian buat lari. (Al Bukhori, t.t.: 24)

Big book merupakan salah satu media pembelajaran yang menyenangkan karena berisi ilustrasi-ilustrasi dan cerita yang menarik dan cara membelajarkannyapun tidak membosankan karena menggunakan metode yang bervariasi. Big book memiliki beberapa keistimewaan, antara lain: 1). Siswa terlibat dalam kegiatan membaca dengan cara yang tidak menakutkan, 2). Semua peserta didk dapat melihat tulisan yang sama ketika guru membacakan tulisan di dalamnya. 3). Siswa dapat bersama-sama memberi makna pada setiap tulisan yang ada pada big book, 4). Peserta didk yang lambat membaca mendapat 
kesempatan untuk mengenali tulisan melalui bantuan guru dan teman-temannya, 5). Mengembangkan semua aspek bahasa; 6). Dapat diselingi percakapan yang relevan dengan isi cerita (Tim Pengembang Modul Pembelajaran PKB Guru, 2020:18-19).

Berdasarkan hal tersebut, maka peneliti bertujuan mendiskripsikan pemanfaatan media big book yang telah digunakan oleh guru Kelas I MI Darussalam Sumowono, Kecamatan Sumowono, Kabupaten Semarang, beliau menyusun big book sesuai dengan tema yang ada di kelas Satu, Big book digunakan sebagai media membaca bersama pada kegiatan pembiasaan. Guru Kelas I MI Darussalam menggunakan big book sebagai media membaca dengan tujuan untuk meningkat kemampuan literasi siswa kelas I MI Darussalam Sumowono pada tema kegemaranku dengan topik gemar membaca, yang mana topik ini merupakan tema ketiga yang dibelajarkan pada awal pertemuan terbatas setelah siswa belajar daring di rumah. Oleh karena itu, penelitian ini bertujuan untuk mengetahui peningkatan literasi siswa kelas I dengan media big book.

\section{B. Metode Penelitian}

Penelitian ini menggunakan pendekatan kualitatif deskriptif degan subyek penelitian adalah siswa kelas I MI Darussalam Sumowono kabupaten Semarang Tahun pelajaran 2021/2022 yang berjumlah 28 siswa, tekhnik pengumpulan data melalui wawancara terhadap guru Kelas I MI Darussalam Sumowono, orang tua siswa kelas I MI Darussalam Sumowono, observasi pada pelaksanaan pembelajaran membaca menggunakan media big book dan dokumentasi pelaksanaan pembelajaran dengan media big book di kelas I. Jenis data yang terkumpul berupa catatan hasil wawancara, informasi dari hasil observasi dan dokumen big book serta foto-foto pelaksnaan .

Data yang terkumpul akan dianalisis dengan teknik analisis content yaitu menganalisis kesesuaian media big book yang telah disusun oleh guru sebagai media membaca dengan modul pembelajaran literasi madrasah ibtidaiyyah UP-4 mengembangkan media big book yang disusun oleh Tim Pengembang modul pembelajran PKB madrasah ibtidaiyyah. pengembangan big book ini untuk meningkatkan literasi kelas siswa kelas 1 MI Darussalam sumowono meliputi keterampilan menyimak, berbicara, membaca dan menulis. 


\section{Hasil Dan Pembahasan}

Media big book dimanfaatkan di Kelas I MI Darussalam Sumowono pada kegiatan pembiasaan 30 menit pada awal pelajaran dengan tujuan untuk meningkatkan literasi siswa kelas I terutama dalam keterampilan membaca. Pada saat pembelajaran daring keterampilan membaca siswa kurang maksimal karena guru tidak bisa secara langsung menyimak dan mendampingi keterampilan membaca siswa dan kurang maksimalanya media yang digunakan. Hal ini diketahui melalui wawancara tertulis kepada orang tua siswa kelas I MI Darussalam yang berjumlah 28 anak.

Tabel 1. Keterampilan membaca siswa saat pembelajaran daring

\begin{tabular}{|c|l|c|}
\hline No & \multicolumn{1}{|c|}{ Indikator } & Keterangan \\
\hline 1 & Belum hafal huruf & 3 siswa \\
\hline 2 & Hafal huruf belum mampu membaca & 8 siswa \\
\hline 3 & Membaca suku kata dengan mengeja & 12 siswa \\
\hline 4 & Lancar membaca & 5 siswa \\
\hline & Jumlah & 28 siswa \\
\hline
\end{tabular}

Berdasarkan hal tersebut, guru kelas I MI Darussalam Sumowono Hj. Aisah, S.Pd.I berinisiatif untuk memanfaatkan media big book sebagai media membaca bersama di kelas I MI Darussalam Sumowono. Big book yang disusun oleh guru mengacu kepada tema yang ada di kelas I SD/MI. Adapun big book yang dibuat berjudul "Kegemaran Hana" yang mengacu pada tema tiga sub tema tiga yaitu gemar membaca. Pemanfaatan media big book pada pembelajaran membaca di kelas I MI Darussalam ini, melalui tahap perencanaan, pelaksanaan, refleksi dan tindak lanjut.

Pada tahap perencanaan terdiri dari dua bagian yaitu membuat big book dan menyusun rencana pelaksanaan pembelajaran (RPP).

a. Tahap membuat Big book

Langkah-langkah membuat big book sesuai yang diperoleh saat pelatihan program keprofesian berkelanjutan guru madrasah ibtidaiyyah dalam pengembangan media big book yaitu: 1). Menentukan topik cerita, 2). Mengembangkan bagian cerita (Tim pengembang modul, 2020: 34-35).

1) Menentukan topik cerita

Topik cerita pada big book yang dibuat adalah "gemar membaca" dengan tokoh utama Hana, Hana merupakan salah satu nama siswa kelas I MI Darussalam Sumowono. Nama tokoh diambil dari nama 
siswa dengan tujuan agar semua siswa penasaran tentang isi cerita sehingga tertarik untuk ikut membaca.

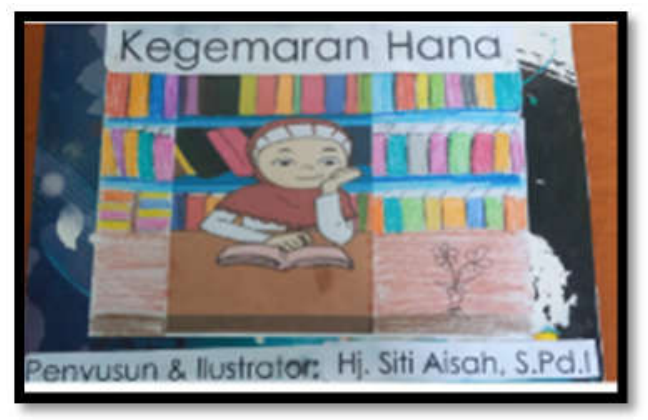

Gambar 1. cover big book

Dengan mengamati cover dari Big book dapat meningkatkant literasi siswa, karena pada cover tertuliskan judul dengan font yang besar untuk dibaca oleh siswa dan ilustrasi atau gambar yang mudah untuk dipahami siswa.

2) Mengembangkan sub bagian cerita

Pada bagian ini, guru membuat alur cerita big book dengan menerapkan $5 \mathrm{~W} 1 \mathrm{H}$ (what/apa, where/ di mana, when/ kapan, who/siapa, why/mengapa dan how/bagaimana). Apakah kegemaran Hana?, apa saja buku bacaan kegemaran Hana? Di mana Hana membaca?, di mana Hana dan teman-temannya membaca?, Kapan Hana membaca?, dengan siapa Hana membaca?, kenapa /bagaimana Hana dapat gemar membaca?.

Melalui mengembangkan sub cerita ini adalah untuk menggali literasi siswa dalam menyimak, berbicara, membaca dan menulis. Karena salah satu tujuan pembelajaran literasi adalah untuk membeantu siswa memahamai dan menemukan strategi yang efektif dalam hal kemampuan membaca dan menuis serta menginterpretasi makna teks yang kompleks dalam struktur tata Bahasa dan sintaks.

3) Menulis cerita

Dalam menulis cerita mengikuti menggunakan $5 \mathrm{~W} 1 \mathrm{H}$ tetapi tidak harus urut dan boleh lebih dari satu, alur cerita pada big book dengan judul "kegemaran Hana", berikut alur cerita big book: 
Tabel 2. Memahami makna kata

\begin{tabular}{|c|l|l|}
\hline Halaman & \multicolumn{1}{|c|}{ Kata tanya } & \multicolumn{1}{c|}{ Kalimat dalam big book } \\
\hline 2 & Who & Hana gemar membaca \\
\hline 4 & Apa saja & $\begin{array}{l}\text { Hana gemar membaca bermacam- } \\
\text { macam buku }\end{array}$ \\
\hline 6 & apa saja & $\begin{array}{l}\text { Ada buku cerita, majalah, buku } \\
\text { pelajaran dan komik }\end{array}$ \\
\hline 4 & Why & Ibu guru mendukung kegemaran Hana \\
\hline 8 & Who & Rani juga gemar membaca \\
\hline 12 & When, who, where & $\begin{array}{l}\text { Waktu istirahat Hana bersama Rani } \\
\text { membaca di perpustakaan }\end{array}$ \\
\hline 14 & When, who, where & $\begin{array}{l}\text { Pulang sekolah, hana bersama teman- } \\
\text { temannya membaca di taman }\end{array}$ \\
\hline 16 & Why & $\begin{array}{l}\text { Membaca dapat menambah ilmu } \\
\text { pengetahun }\end{array}$ \\
\hline
\end{tabular}

Setelah alur cerita lengkap guru mencari gambar di buku siswa tema kegemaranku, sub tema gemar membaca kemudian diperbesar dan ditempel pada buku gambar A3 dan membuat kalimat dengan font century Gothic 100 agar tulisan mudah dibaca dari kejauhan, halaman sebelah kanan berisi gambar dan halaman kiri berisi kalimat sesuai gambar.

b. Penyusunan Rencana Pelaksanaan Pembelajaran

Rencana pelaksanaan pembelajaran pemanfaatan big book untuk membaca bersama di kelas I MI darussalam adalah sebagai berikut:

1) Kegiatan Awal

- Pada kegiatan awal guru menyiapkan big book, LKPD dan kartu kata.

- Guru membuka kegiatan dengan salam, berdoa, menyapa siswa menanyakan kabar dan kesiapa untuk melakukan kegiatan.

- Melakukan apersepsi sebagai awal komunikasi dengan mengajukan tentang kegemaran siswa.

- Menyampaikan tujuan kegiatan yaitu diharapkan siswa dapat menjawab pertanyaan sesuai isi teks bacaan dan secara berkelompok membuat buku mini sesuai cerita.

- Guru meminta siswa duduk di lantai yang telah dipasang karpet untuk membaca big book bersama.

2) Kegiatan Inti

- Guru memperlihatkan cover buku kepada siswa dan memperkenalkan namanya big book dengan judul yang masih ditutup dengan kertas, kemudian dilanjutkan Tanya jawab antara lain : ada gaabar apa di cover ini?, menurutmu tentang apakah cerita ini? Apakah kalian dapat menebak judul buku ini?, guru membuka kertas penutup judul kemudian mengajak siswa bersama-sama membaca judul big book.

- Guru membuka halaman 1 pada big book yang isinya sama dengan cover dan meminta siswa mengulang membacanya kembali.

- Guru meminta siswa menebak kira-kira di halaman selanjutnya ada gambar apa. 
- Siswa menebak isi halaman 2-3, kemudian guru membuka halaman 2dan memperlihatkan gambar (halaman 3), tanya jawab isi gambar dengan kata tanya apa yang kegemaran Hana?, dengan jawaban siswa, guru mencocokkkan kalimat yang tertulis di halaman dua, kemudian membaca bersama, sampai semua siswa dapat membaca kalimat tersebut.

- Guru mengadakan tanya jawab tentang kata "gemar".

- Kemudian guru membuka halam selanjutnya diawali dengan memperlihatkan gambar, tanya jawab isi gambar dan membaca kalimat secara berulang-ulang. Dilakukan sampai halaman terakhir.

3) Kegiatan akhir

- Menyimpulkan bersama isi bacaan

- Siswa melakukan evaluasi secara kelompok dan individu dengan cara guru membagikan gambar-gambar kecil sesuai isi big book, siswa berdiskusi mengurutkan dan menulis kalimat sesuai gambar kemudian membaca kalimat dengan nyaring di depan kelas secara bergantian.

- Refleksi kegiatan membaca dengan cara siswa membuat emoji suka atau tidak suka pada lingkaran kecil yang telah disediakan.

- Kegiatan ditutup dengan bacaan hamdalah dan salam

Setelah perencanaan dibuat, selanjutnya pelaksanaan membaca bersama dengan pemanfaatan big book dilaksanakan sesuai rencana pelaksanaan membaca. Dengan pemanfaatan media big book ini keterampilan membaca siswa kelas 1 dapat meningkat dengan hasil sebagai berikut:

Diagram 1 : Keterampilan membaca siswa kelas 1

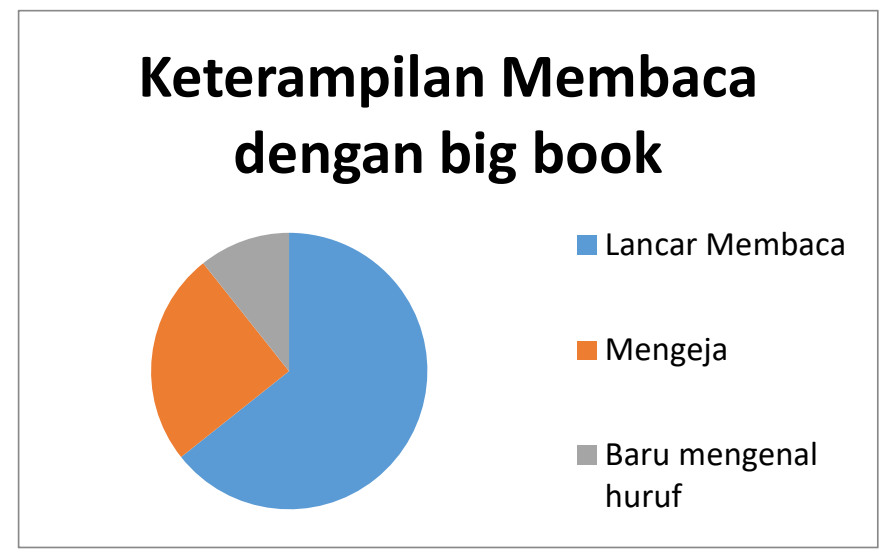

Berdasarkan diagram di atas, dari 28 siswa yang sudah lancar membaca big book dengan judul "kegemaran Hana" adalah 18 siswa, membaca dengan mengeja 7 siswa dan masih perlu bimbingan 3 siswa. Selain keterampilan membaca adalah siswa juga dapat memahami beberapa makna kata melalui tanya jawab yang terdapat pada kalimat.

Pemanfaatan big book ini, juga melatih keterampilan menyimak dan berbicara karena dalam kegiatan membaca selalu diisi dengan tanya jawab dan 
pada kegiatan siswa mampu menceritakan kembali isi big book dengan kalimatnya sendiri, serta mampu membuat buku kecil atau mini book yang dibuat secara berkelompok. Pada kegiatan akhir, siswa menulis kosakata baru sebagai kemampuan literasi menulis yang diperoleh dari membaca big book kemudian membacanya secara nyaring . hasil evaluasi menunjukkan bahwa $89,28 \%$ siswa mampu menulis kalimat.

Setelah membaca dengan big book dilaksanakan maka perlu diadakan refleksi. Refleksi merupakan cara berpikir tentang apa-apa yang sudah dilakukan dan merupakan respon terhadap kejadian, aktivitas atau pengetahuan yang yang baru diterima (Pranyoto, 2014). Adapun yang dilaksanakan guru untuk merefleksi kegiatan membaca bersama dengan memafaatkan big book adalah guru memberikan kertas berbentuk lingkaran yang dibagikan kepada siswa, selanjutnya siswa memberikan gambar emoji senyum bagi yang suka dengan pemanfaatan big book dan menggambar emoji cemberut bagi yang tidak suka.

Penggunaan media big book yang telah disusun sudah sesuai dengan kriteria pengembangan big book pada modul pengembangan literasi madrasah ibtidaiyyah. Dari segi manfaat big book yang disusun sudah memberikan kesempatan kepada anak untuk terlibat dalam situasi nyata dengan cara yang menarik, semua anak dapat melihat tulisan pada big book sama ketika guru membaca tulisan tersebut, siswa dapat bekerjasama memberi makna kepada tulisan di dalamnya, penggunaan big book dapat mengembangkan kemampuan dasar anak dalam semua aspek Bahasa yaitu mendengarkan, berbicara, membaca dan menulis (Pengembang Modul pembelajaran PKB guru Madrasah Ibtidaiyyah, 2020:3).

Langkah-langkah dalam membuat big book juga sudah sesuai dengan modul yaitu: kertas yang digunakan minimal berukuran A3 sebanyak 8-10 halaman atau 10-15 halaman, menentukan topik cerita, mengembangkan topik cerita menjadi certa yang utuh dalam kalimat-kalimat singkat, menentukan gambar atau ilustrasi untuk setiap halaman dan mendesain cerita dan gambar atau ilustrasi (Pengembang Modul pembelajaran PKB guru Madrasah Ibtidaiyyah, 2020:25). Penggunaan big book "Kegemaran Hana" sesuai dengan ketentuan pada modul. yaitu: big book dapat digunakan setiap hari 15-20 menit, Big book dibacakan di depan kelas, big book dapat digunakan oleh peserta didik untuk 
dibacakan di depan teman-temannya (Pengembang Modul pembelajaran PKB guru Madrasah Ibtidaiyyah, 2020:26).

Berdasarkan hal tersebut, maka big book yang telah disusun oleh guru kekas I MI Darussalam dengan judul "Kegemaran Hana" untuk digunakan sebagai media membaca dalam kegiatan pembiasaan untuk meningkatkan literasi siswa dapat dikembangkan lagi pada topik, cerita atau mata pelajaran yang lain.

\section{Kesimpulan}

Media big book berjudul "Kegemaran Hana" digunakan pada kegiatan pembiasaan membaca bersama sebelum pelajaran dimulai. Penggunaan media big book memberikan banyak manfaat yaitu memberikan kesempatan kepada siswa terlibat dalam situasi nyata dengan cara yang menarik, semua anak dapat melihat tulisan pada big book, siswa dapat bekerjasama memberi makna kepada tulisan di dalamnya, dapat mengembangkan kemampuan dasar anak dalam semua aspek bahasa yaitu mendengarkan, berbicara, membaca dan menulis. Selain itu, keterampilan literasi yang diperoleh siswa Keals I melalui membaca dengan big book meliputi keterampilan membaca, menyimak, memahami makna, keterampilan berbicara, dan menulis.

\section{E. Ucapan Terima Kasih}

Paparan dalam artikel ini merupakan hasil penelitian dengan harapan dapat dijadikan sebagai inspirasi bagi guru dalam meningkatkan kegiatan literasi sekolah. Ucapan terima kasih kami haturkan kepada semua pihak terutama kepada kepala MI Darussalam Sumowono, orang tua siswa, dan seluruh siswa kelas 1 MI Darussalam Sumowono Kabupaten Semarang. 


\section{Daftar Pustaka}

Al Bukhori, A. A. bin I. (t.t.). Matn Bukhori Masykul: Vol. I. Dar al Ma'rifat.

Alnashr, M. S. (2018). Integrasi Pendidikan Siaga Bencana dalam Kurikulum Madrasah Ibtidaiyah. MAGISTRA: Media Pengembangan Ilmu Pendidikan Dasar dan Keislaman, 6(2). https://doi.org/10.31942/mgs.v6i2.1779

Alpusari, M., Mulyani, E. A., Putra, R. A., \& Hermita, N. (2021). Pengembangan Big book Sekolah Dasar. Tunjuk Ajar: Jurnal Penelitian Ilmu Pendidikan, Volume 4, Nomer 1.

Badan Wakaf Indonesia. (2020). Laporan Hasil Survey Indeks Literasi Wakaf 2020. 1, 7 8.

Bahaudin, N. S., \& Zaini. (2007). Al Qur'an dan Tafsirnya: Vol. X. UII Press Yogyakarta.

Bu'ulolo, Y. (2021). Membangun Budaya Literasi di Sekolah. Bahasa Indonesia Prima (BIP), 3(1), 16-23.

Creswell, J. W. (2019). Research Design Pendekatan Metode Kualitatif, Kuantitafif, dan Campuran. Pustaka Pelajar.

Dirwan, D., Bunyamin, B., \& Umrah, S. (2018). Perintah Membaca dalam A1Qur'an Perspektif Pendidikan (Surah Al-Alaq). AL-FIKR: Jurnal Pendidikan Islam, 4(2), 34-47.

Harras, K. A. (2011). Hakekat Membaca. Jakarta: Depdikbud PPGLTP.

Husna, M., \& Sugito, S. (2021). Eksplorasi Penerapan Pembelajaran Tatap Muka Terbatas pada Jenjang PAUD di Masa Kebiasaan Baru. Jurnal Obsesi: Jurnal Pendidikan Anak Usia Dini, 6(3), 1846-1858.

Ma'Arif, S. (2018). Education as a foundation of humanity: Learning from the pedagogy of pesantren in Indonesia. Journal of Social Studies Education Research, 9(2), 104-123. https://doi.org/10.17499/jsser.58854

Mahsun, M., \& Koiriyah, M. (2019). Meningkatkan Keterampilan Membaca melalui Media Big book pada Siswa Kelas IA MI Nurul Islam Kalibendo Pasirian Lumajang. Bidayatuna: Jurnal Pendidikan Guru Madrasah Ibtidaiyah, 2(1), 6078.

Oktavia, L. S. (2021). Perkembangan Anak Usia Sekolah Dasar: Kajian Untuk Siswa Kelas Rendah. 5, 6.

Paramita, V., Hartati, I., \& Rifiani, A. H. (2016). Prosiding SNST ke-7 Tahun 2016 Fakultas Teknik Universitas Wahid Hasyim Semarang 7. Prosiding SNST.

Pranyoto, Y. H. (2014). Paradigma Pedagogi Refleksi (PPR). Jurnal Masalah Pastoral, $3(1), 19-19$.

Pratiwi, E. (2019). Pembelajaran Calistung bagi Anak Usia Dini antara Manfaat Akademik dan Resiko Menghambat Kecerdasan Mental Anak. 278-283.

Puspaningrum, R. D. (2015). Pengaruh penggunaan media big book terhadap kemampuan literasi informasi siswa sekolah dasar.

Syakroni, A., Zamroni, Muali, C., Baharun, H., Sunarto, M. Z., Musthofa, B., \& Wijaya, M. (2019). Motivation and Learning Outcomes Through the Internet of Things; Learning in Pesantren. Journal of Physics: Conference Series. https://doi.org/10.1088/1742-6596/1363/1/012084

Tim Pengembang Modul Pembelajarn PKB Guru. (2020). Modul Literasi. Kementerian Agama Republik Indonesia Direktorat Jenderal Pendidikan Islam. 